\title{
Panax Notoginseng Saponins: A Review of Its Mechanisms of Antidepressant or Anxiolytic Effects and Network Analysis on Phytochemistry and Pharmacology
}

\author{
Weijie Xie ${ }^{1,2,3,4}$ (D), Xiangbao Meng 1,2,3,4, Yadong Zhai 1,2,3,4 , Ping Zhou 1,2,3,4, \\ Tianyuan Ye 1,2,3,4, Zhen Wang 1,2,3,4, Guibo Sun 1,2,3,4,* and Xiaobo Sun 1,2,3,4,* \\ 1 Beijing Key Laboratory of Innovative Drug Discovery of Traditional Chinese Medicine (Natural Medicine) \\ and Translational Medicine, Institute of Medicinal Plant Development, Peking Union Medical College and \\ Chinese Academy of Medical Sciences, Beijing 100193, China; ginseng123@163.com (W.X.); \\ xbmeng@implad.ac.cn (X.M.); zydmailbox@163.com (Y.Z.); zhoup0520@163.com (P.Z.); \\ yetianyuan2013@163.com (T.Y.); 15128475758@163.com (Z.W.) \\ 2 Key Laboratory of Bioactive Substances and Resource Utilization of Chinese Herbal Medicine, \\ Ministry of Education, Beijing 100193, China \\ 3 Key Laboratory of Efficacy Evaluation of Chinese Medicine against Glycolipid Metabolic Disorders, \\ State Administration of Traditional Chinese Medicine, Beijing 100193, China \\ 4 Zhongguancun Open Laboratory of the Research and Development of Natural Medicine and Health Products, \\ Beijing 100193, China \\ * Correspondence: sunguibo@126.com (G.S.); sun_xiaobo163@163.com (X.S.); \\ Tel.: +86-10-5783-3220 (G.S.); +86-10-5783-3013 (X.S.)
}

Received: 14 March 2018; Accepted: 6 April 2018; Published: 17 April 2018

\begin{abstract}
Panax notoginseng (Burk) F. H. Chen, as traditional Chinese medicine, has a long history of high clinical value, such as anti-inflammatory, anti-oxidation, inhibition of platelet aggregation, regulation of blood glucose and blood pressure, inhibition of neuronal apoptosis, and neuronal protection, and its main ingredients are Panax notoginseng saponins (PNS). Currently, Panax notoginseng (Burk) F. H. Chen may improve mental function, have anti-insomnia and anti-depression effects, alleviate anxiety, and decrease neural network excitation. However, the underlying effects and the mechanisms of Panax notoginseng (Burk) F. H. Chen and its containing chemical constituents (PNS) on these depression-related or anxiety-related diseases has not been completely established. This review summarized the antidepressant or anxiolytic effects and mechanisms of PNS and analyzed network targets of antidepressant or anxiolytic actions with network pharmacology tools to provide directions and references for further pharmacological studies and new ideas for clinical treatment of nervous system diseases and drug studies and development. The review showed PNS and its components may exert these effects through regulating neurotransmitter mechanism (5-HT, DA, NE), modulation of the gamma-amino butyric acid (GABA) neurotransmission, glutamatergic system, hypo-thalamus-pituitary-adrenal (HPA) axis, brain-derived neurotrophic factor (BDNF), and its intracellular signaling pathways in the central nervous system; and produce neuronal protection by anti-inflammatory, anti-oxidation, or inhibition of neuronal apoptosis, or platelet aggregation and its intracellular signaling pathways. Network target analysis indicated PNS and its components also may have anti-inflammatory and anti-apoptotic effects, which leads to the preservation of brain nerves, and regulate the activity and secretion of nerve cells, exerting anti-depression and anxiolytic effects, which may provide new directions for further in-depth researches of related mechanisms.
\end{abstract}

Keywords: antianxiety; antidepression; panax notoginseng saponins; network pharmacology; review 


\section{Introduction}

Depression is a chronic and recurrent syndrome of mood disorder with significant and lasting low mood [1-4]. Clinical depressed patients are characteristic of its disproportionate, emotional depression, being not commensurate with their situation, low self-esteem, and even pessimism, including depressed mood from depression to grief. Some may have suicide attempts or behaviors [5,6]; in severe cases, there may be hallucinations, delusions, and other psychotic symptoms [7]. The pathogenesis and etiology of still remain unknown [8-14]. However, today's knowledge proposes multiple neuronal and hormonal systems involved in the pathophysiology of the disease. Current evidence suggests that the occurrence of depression may be related to a reduced secretion of neurotransmitters [15-17], such as dopamine (DA), norepinephrine (NE), and serotonin (5-HT), neuronal apoptosis [14,18,19], inflammation [20-23], intestinal flora [18], and other factors [16,18,24,25]. There are currently four classes of antidepressant drugs and atypical antidepressants $[25,26]$. However, these drugs have undesirable side effects, with high relapse rates and a long onset of therapeutic action. Therefore, critically important is the development of efficient and safe drugs for the treatment of depression.

Panax notoginsen (Burk) F. H. Chen (Sanqi in Chinese) is a commonly used Chinese medicine, the root of which has been used for the treatment of hemoptysis, hemostatic, and hematoma in China and other Asian countries for its hemostatic and cardiovascular effects for more than several hundred years [26-28]. To the best of our knowledge, over 200 chemical constituents have been isolated from Panax notoginseng (Burk) F. H. Chen, but the main ingredients are Panax notoginseng saponins (PNS) [29], being classified into four types: protopanaxadiol, protopanaxatriol, ocotilloltype, and oleanolic acid constituents. There are others reported to be flavonoids, cyclopeptides, saccharides, and inorganic elements [30]. Pharmacological studies have shown that notoginseng and its extracts have many functions, such as anti-inflammatory [16,20,31,32], anti-oxidation, inhibition of platelet aggregation, regulation of blood glucose [27,33,34] and blood pressure [35-37], inhibition of neuronal apoptosis [14,38,39], and neuronal protection [30].

Recent studies have found that PNS have good preventive and therapeutic effects on neurological diseases of the brain [28], especially in antidepressant [26-28] and anti-anxiety effects [25,28,40]. The preliminary determination was that anti-depressant and anti-anxiety effects may occur by increasing the levels of the brain monoamine neurotransmitters 5-hydroxytryptamine (5-HT) [41,42] and norepinephrine (NE) in the central nervous system. Experiments also have shown that PNS modulates $\mathrm{Na}^{+}$currents and $\mathrm{Ca}^{2+}$ concentrations, and increases nestin and brain-derived neurotrophic factor (BDNF) $[14,19,29,43-47]$. Moreover, PNS or single compounds exerted antidepressant-like effects by regulating the release of interleukin (IL)-1 $\beta$, IL-6, and tumor necrosis factor (TNF)- $\alpha$, or anti-inflammatory cytokines IL-4 and IL-10 [10,20,29,31,32,36,48-56]. Such breakthroughs have been made to determine there are antidepressant effects on estrogen in the human body. Estrogen can act on the PI3K/Akt, MAPK/ERK, mTORC1, and other signaling pathways, and then these pathways are regulated by growth factors that protect neurons and produce estrogen-like effects on synapses. However, the role of PNS or its single compounds in normal function and in disease remains to be not much elucidated.

Therefore, this review summarized the antidepressant or anxiolytic effects and mechanisms of PNS and analyzed network targets of antidepressant or anxiolytic actions with network pharmacology tools, to provide reference for further pharmacological studies and new ideas for clinical treatment of nervous system diseases and drug studies and development.

\section{Mechanisms of Antidepression}

\subsection{Panax Notoginseng Saponins}

Modern pharmacological studies have found Panax notoginseng saponins (PNS) have good preventive and therapeutic effects of brain neurological diseases [26,28,57]. Ginsenosides Rg1, Rb1, $\mathrm{Re}$, and notoginsenoside $\mathrm{R} 1$, as the representative [26,28,57], showed anti-depressant and anti-anxiety 
activity [28,31,35,58-61]. The evaluation methods of antidepressant effects include sucrose preference test (SPF) [62], forced swimming test (FST) [63-65], open field test (OFT) [62,64,66], elevated plus-maze (EPM) test, and tail suspension test (TST) [66].

PNS (58.6\%) significantly decreased immobility time in the forced swim test with little effect on locomotion in the chronic mild stress model, and significantly improved the level of animal activity and sucrose consumption [67], which may have antidepressant-like effects $[45,53,64,65]$. Besides this, when PNS was digested by Snail Enzyme to 50\%, it produced the best antidepressant effects, and the main active ingredient includes ginsenosides $\mathrm{Rb} 1, \mathrm{Rb} 2, \mathrm{Rc}$, and $\mathrm{Rb} 3$ [40,60,68-70]. These were shown in Table 1.

At present, the antidepressant mechanisms have been partly proved to be that PNS upregulates expression of brain-derived neurotrophic factor (BDNF) by regulating multiple upstream neural signal transduction pathways, including AC/cAMP/PKA $[45,71]$ and mitogen-activated protein kinase channels (TrKB/MAPK/PSK) [37,72]; meanwhile, PNS regulates calmodulin kinase channel $\left(\mathrm{Ca}^{2+} / \mathrm{CaM} / \mathrm{CaMK}\right)$, reduces internal concentration of $\mathrm{Ca}^{2+}$ in nerve cells [73], and promotes the release of neurotransmitters 5-HT, NE, and DA [27,32,41,52]. Thereby, PNS exerted its antidepressant-like effect. These are shown in Table 1.

Besides this, both PNS and ginseng total saponin (GTS) have significant antidepressant effects on LPS-induced murine CD-1 mouse models $[19,52,53,74]$ by reducing mRNA levels for IL-1 $\beta$, IL-6, TNF- $\alpha$, and indoleamine 2,3-dioxygenase (IDO) in hippocampus [52]. These were shown in Table 1.

Table 1. Phytochemicals and mechanisms with antidepressant effects in Panax notoginseng saponins (PNS).

\begin{tabular}{|c|c|c|c|}
\hline Name & Methods & Models & Neurobehavioral Effects and Mechanisms \\
\hline PNS $(58.6 \%)$ & $\begin{array}{l}\text { OFT; TST; } \\
\text { FST; SPT } \\
{[26,53]}\end{array}$ & $\begin{array}{l}\text { CMS-induced mice; } \\
\text { CUMS-induced rats } \\
{[26,53]}\end{array}$ & $\begin{array}{l}\downarrow \text { Immobility time in FST and TST; } \uparrow \text { sucrose intake in sucrose } \\
\text { preference test; } \uparrow \text { level of animal activity; } \uparrow \text { Expression of BDNF } \\
{[40,60,68-70] .}\end{array}$ \\
\hline Purified PNS & $\begin{array}{l}\text { SPT; OFT } \\
{[45,71]}\end{array}$ & $\begin{array}{l}\text { CUMS-induced SD } \\
\quad \text { rats }[45,71]\end{array}$ & $\begin{array}{l}\text { Regulate upstream neural signal transduction pathways: } \\
\text { AC/cAMP/PKA, TrKB/MAPK/PSK and } \mathrm{Ca}^{2+} / \mathrm{CaM} / \mathrm{CaMK} \\
\text { signaling pathway; } \\
\downarrow \text { Concentration of } \mathrm{Ca}^{2+} \text { in nerve cells; } \uparrow \text { release of } \\
\text { neurotransmitter } 5-\mathrm{HT}, \mathrm{DA} \text {, and NE }[45,71] .\end{array}$ \\
\hline PNS and GTS & $\begin{array}{l}\text { FST; SPT } \\
{[53,75-78]}\end{array}$ & $\begin{array}{l}\text { LPS-induced KM } \\
\text { mice; CD-1 mice } \\
\quad[53,75-78]\end{array}$ & $\begin{array}{l}\downarrow \text { mRNA of IL-1 } \beta, \text { IL- } 6 \text {, TNF- } \alpha \text {, and IDO; } \downarrow \text { Inflammation in the } \\
\text { brain }[53,75-78] \text {. }\end{array}$ \\
\hline Ginsenoside Rg1 & $\begin{array}{l}\text { OFT; FST; SPT } \\
{[19,45]}\end{array}$ & $\begin{array}{l}\text { CMS and } \\
\text { CUMS-induced } \\
\text { depression Animal } \\
\text { Model }[19,45]\end{array}$ & $\begin{array}{l}\downarrow \text { CMS-induced increasement of corticosterone levels in serum; } \\
\uparrow \text { CUMS-induced CREB phosphorylation in the amygdala of the } \\
\text { brain [45]; } \uparrow \text { expression of BDNF }[33,43] \text {; regulate hyperactivity } \\
\text { of the HPA axis in depressed states; } \uparrow \text { neuronal status, neurons } \\
\text { quantity and density of dendritic spines }[19,45] \text {. }\end{array}$ \\
\hline Ginsenoside Rg1 & FST; SPT [79] & $\begin{array}{l}\text { CMS and } \\
\text { CUMS-induced } \\
\text { depression animal } \\
\text { model [80] }\end{array}$ & $\begin{array}{l}\uparrow \text { Expression of connexin and gap junction of astrocytes in the } \\
\text { prefrontal cortex of the brain; } \uparrow \text { dense ultrastructure; } \\
\downarrow \text { permeability and depression-like behaviors induced by CUS } \\
\text { in rats [79]. }\end{array}$ \\
\hline Ginsenoside Rg1 & FST; SPT [10] & $\begin{array}{l}\text { Cerebral } \\
\text { inflammatory model } \\
\text { mice [10] }\end{array}$ & $\begin{array}{l}\downarrow \text { Recruitment of Ly6C (hi) monocytes in inflammatory brain } \\
\text { model mice [10,16]; activate THP-1 monocytes; blocks the } \\
\text { feedback-regulated release of CCL2 from astroglial cells; } \\
\downarrow \text { CCL2 signaling pathways: p38/MAPK and PI3K/Akt } \\
\text { activities [10,81]. }\end{array}$ \\
\hline Ginsenoside Rg1 & $\begin{array}{l}\text { TST; FST; SPT } \\
\quad[15,67]\end{array}$ & $\begin{array}{l}\text { CUMS-induced } \\
\text { depression rats [67] }\end{array}$ & $\begin{array}{l}\downarrow \text { Contents of Glu and Asp in hippocampus, } \uparrow \text { contents of GABA } \\
\text { and Tau; } \downarrow \text { depression-like Behavior in CUMS model rats }[15,67]\end{array}$ \\
\hline $\begin{array}{l}\text { Ginsenoside } \\
\text { Rb1 and } \\
\text { ginsenoside K }\end{array}$ & TST; FST [42] & $\begin{array}{l}\text { CUMS-induced } \\
\text { depression rats [42] }\end{array}$ & $\begin{array}{l}\uparrow \text { Expression of 5-HT2AR mRNA and activate of 5-HT2AR [42]; } \\
\text { the antidepressant effects of Rb1 and the metabolite ginsenoside } \\
\text { K may be antagonized by 5-HT2AR antagonists (Ritanerin), } \\
\text { indicating that Rb1 has a similar 5-HT transmitter activation } \\
\text { effect }[68,82,83] \text {. }\end{array}$ \\
\hline
\end{tabular}


Table 1. Cont.

\begin{tabular}{cccl}
\hline Name & Methods & Models & \multicolumn{1}{c}{ Neurobehavioral Effects and Mechanisms } \\
$\begin{array}{c}\text { Ginsenoside } \\
\text { Rg3 and } \\
\text { ginsenoside Rh2 }\end{array}$ & $\begin{array}{c}\text { OFT; SPT } \\
{[19,53,74]}\end{array}$ & $\begin{array}{c}\text { LPS-induced mice } \\
\text { [19,53,74] and } \\
\text { CSDS-induced mice } \\
\text { [74] }\end{array}$ & $\begin{array}{l}\downarrow \text { IL-6 and TNF- } \alpha \text { in plasma and the expression of indoleamine } \\
\text { 2,3-dioxygenase (IDO) in brain; } \downarrow \text { turnover of tryptophan and } \\
\text { 5-HT in hippocampal tissue; regulate secretory activities of } \\
\text { microglia and transcription of NF-kappa-B in nuclear; } \\
\uparrow \text { expression of BNDF; } \downarrow \text { depressive behavior or } \\
\text { symptoms [53,74,84]. }\end{array}$ \\
\hline Ginsenoside Rg5 & OFT; FST; SPT & $\begin{array}{c}\text { CSDS-induced mice } \\
\text { [85] }\end{array}$ & $\begin{array}{l}\downarrow \text { Trk and AchE; } \uparrow \text { expression of BNDF [69,85]. } \\
\text { Ginsenoside Re }\end{array}$ \\
& OFT; TST [44] & $\begin{array}{c}\text { CMS-induced rat } \\
\text { model [44] }\end{array}$ & $\begin{array}{l}\text { Regulate the central adrenergic system; } \downarrow \text { expression of TH in } \\
\text { the locus coeruleus area; } \downarrow \text { decrease of BDNF in the } \\
\text { hippocampus, and regulates the secretion of corticosterone from } \\
\text { the HPA axis [44]. }\end{array}$ \\
\hline
\end{tabular}

GST, ginseng total saponin ; SPT, sucrose preference test; FST, forced swimming test; OFT, open field test; TST, tail suspension test; CMS, chronic mild stress; CUMS, chronic unpredictable mild stress; CREB, cAMP response element-binding protein; CSDS, chronic social defeat stress.

\subsection{Single Component: $\operatorname{Rg} 1$}

Among Panax notoginseng saponins, ginsenoside Rg1, Rb1, Rc, and Rb3 are important representative components of PNS antidepressant, belonging to the original ginseng diol type saponins, and the contents of ginsenoside Rb3 and Rc were $17.66 \%$ and $9.32 \%$, respectively $[25,27,33]$.

By conducting open field tests (OFT), tail suspension tests (TST), forced swimming tests (FST), or sugar consumption tests, ginsenoside Rg1 showed antidepressant effect in chronic mild stress (CMS)or chronic unpredictable mild stress (CUMS)-induced animal models of Depression $[45,64,67,80]$. Ginsenoside Rg1 significantly reversed increase of serum corticosterone induced by CMS, increased the phosphorylation of cAMP response element-binding protein (CREB) in rat cerebral amygdala induced by CUMS, up-regulated expression of BDNF in the hippocampus [32,43,45], and down-regulated serum corticosterone lever [43]. It also regulates the hyperthyroidism of HPA axis in depression, plays a positive role in activating BDNF and protein kinase [43,74], and also improves the neuronal status, and increases the number of neurons and dendritic spine density $[32,43,45]$, producing antidepressant effect.

Moreover, ginsenoside Rg1 could up-regulate the expression of connexin, improve the gap junctional connectivity of astrocytes in the prefrontal cortex, decrease the permeability, increase the ultrastructure, and reduce the depression-like behavior of rats induced by CUMS [79]. As present studies found that Ly6C (hi) blood mononuclear cells can be used as anti-depressant regulatory targets [10], Rg1 selectively suppressed Ly6C hi monocytes recruitment to the inflamed mice brain [10], Rg1 pretreatment on activated THP-1 monocytes retarded their ability to trigger CCL2 secretion from co-cultured U251 MG astrocytes, and CCL2-triggered p38/MAPK and PI3K/Akt activation were blocked by $\operatorname{Rg} 1[10,81]$. Besides this, Rg1 suppressed depression-like behaviors in CUMS model rats by reducing contents of Glu and Asp in hippocampus and increasing GABA and Tau content, exerting antidepressant effects [67].

\subsection{Single Component: $R b 1$}

Ginsenoside Rb1 and ginsenoside $\mathrm{K}$, its metabolite, could activate 5-HT2AR, and may also up-regulate the mRNA expression of 5-HT2AR, which showed anti-depressant effects on ovariectomized rat model carried with ovariectomy, whereas the anti-depression effect of $\mathrm{Rb} 1$ and ginsenoside K may be reversed by the 5-HT2AR antagonist (ritanserin), which generally indicates that $\mathrm{Rb} 1$ has a similar-neurotransmitter of 5-HT activation effect [42]. These were shown in Table 1. 


\subsection{Single Component: Rb3}

Ginsenoside Rb3 had significant anti-immobility effects in mice in the forced swim and tail suspension tests, and reduced the number of escape failures in the learned helplessness procedure by using the forced swimming test, tail suspension test, and learned helplessness procedure. Biochemical variations (i.e., brain-derived neurotrophic factor and the monoamine neurotransmitters 5-hydroxytryptamine, dopamine, and norepinephrine) are mainly involved in Rb3's antidepressant-like effects [25,27]. Using $\mathrm{GABA}_{\mathrm{A}}$ receptor agonist muscimol was similar to that of ginsenoside $\mathrm{Rb3}$, which indicated that the activation of the $\mathrm{GABA}_{\mathrm{A}}$ receptor is correlated with the neuroprotective mechanisms of ginsenoside $\mathrm{Rb3}[25,27,86]$. These were shown in Table 1.

\subsection{Single Component: $\operatorname{Rg} 3$}

Ginsenoside Rg3 exerted a significant antidepressant effect on LPS-induced mouse model by immunomodulatory and anti-inflammatory effects $[19,53,74]$, which decreased levels of IL-6, TNF- $\alpha$ in plasma and indoleamine-2,3-deoxygenates (IDO) expression in the hippocampus, reduced or inhibited the turnover of the tryptophan-serotonin $(5-\mathrm{HT})$ in the hippocampus, regulated the secretory activity of microglia microglial cells and the transcription of NF-kappa-B in the nucleus, and repaired tryptophan-kynurenine metabolic balance, thereby weakening the depressant-like behavior or symptoms. In addition, Rg3 exerted an anti-depressant effect on chronic social defeat stress (CSDS)-induced mice model, but had no significant effect on animal activity and enhanced BNDF expression [74]. These were shown in Table 1.

Besides this, ginsenoside Rg5 induced antidepressant effect by inhibiting Trk and AchE activity and upregulating BDNF expression in chronic social defeat stress (CSDS)-induced model mice [85]. Ginsenoside Re regulated the central adrenergic system, inhibited tyrosine hydroxylase (TH) expression in the locus coeruleus, blocked the decrease of BDNF in hippocampus, and regulated the secretion of corticosterone in the HPA axis, thus alleviating and regulating the synthesis of depression or anxiety symptoms [44]. These were shown in Table 1.

\section{Mechanisms of Antianxiety}

At present, representatives of Panax notoginseng (Burk) F. H. Chen, stem and leaf soap components or part of ginsenosides that have been shown to have anxiolytic effects are ginsenoside $\mathrm{Rb} 1, \mathrm{Re}$, PPD [40,83,87,88], ginsenoside Rh1 [40], and ginsenoside Rg3 [27,53,74,84]. In chronic mild stress (CMS)-induced rats, l-DOPA-induced running behavior in mice or 5-HTP-induced head-twitch tests, PNS decreased immobility time, increased the levels of 5-hydroxytryptamine, dopamine, and noradrenaline, reduced basal $\left[\mathrm{Ca}^{2+}\right]_{\mathrm{i}}$ levels in cultured neurons, which were mediated by modulation of brain monoamine neurotransmitters and intracellular $\mathrm{Ca}^{2+}$ concentration, producing anti-anxiety and antidepressant effect $[26,28,89]$. These are shown in Table 2.

Ginsenoside $\mathrm{Rb} 1$ reduced the anxiety index, increased the risk assessment, reduced grooming behaviors in the EPM test, and increased the total number of line crossings of an open field in single prolonged stress (SPS)-induced model and in model rats of post-traumatic stress disorder (PTSD) by increasing the expression of neuropeptide $\mathrm{Y}$ induced by SPS-induced decrease in hypothalamic; increase the expression of tyrosine hydroxylase in locus coeruleus and decrease the mRNA expression of BDNF in hippocampus.

At the same time, ginsenoside Rb1 and Re's intestinal metabolites PPD and K, ginsenoside Rh1 can increase arm opening time in EPM and reduce the serum levels of adrenone IL- 6 , and the role of $\gamma$-aminobutyrate-A (GABA A) receptor(s) exert anxiolytic effects [27,40]. Pseudoginsenoside- $\mathrm{F}(11)$ greatly ameliorated the anxiety-like behaviors induced by MA, shortened MA-induced prolonged latency, decreased the error counts, significant decreases in the contents of dopamine (DA), 3,4-dihydroxyphenacetic acid (DOPAC), homovanillic acid (HVA), and 5-hydroxyindoacetic acid (5-HIAA) in the brain of MA-treated mice; and partially, but significantly, a antagonize MA-induced 
decreases of DA [90]. Besides, Ginsenoside Rg3, Rh2, Rg1 and Ro significantly increased both the frequency and duration of open arm entries, indicating that ginsenoside $\mathrm{Rb} 1$ is one of the active anxiolytic components [84]. These were shown in Table 2.

Table 2. Phytochemicals and mechanisms with anxiolytic effects in Panax notoginseng saponins (PNS).

\begin{tabular}{|c|c|c|c|}
\hline Name & Methods & Models & Neurobehavioral Effects and Mechanisms \\
\hline PNS & $\begin{array}{l}\text { OFT; SPT } \\
{[26,28]}\end{array}$ & $\begin{array}{l}\text { 1-DOPA-induced } \\
\text { mice }[26,28] \\
\text { 5-HTP-induced } \\
\text { rats [89] }\end{array}$ & $\begin{array}{l}\downarrow \text { Basal }\left[\mathrm{Ca}^{2+}\right]_{\mathrm{i}} \text { levels; } \downarrow \text { immobility time; } \uparrow \text { levels of } 5 \text {-HT, DA } \\
\text { and NE }[26,28,89] \text {. }\end{array}$ \\
\hline Ginsenoside Rb1 & $\begin{array}{l}\text { EPM test } \\
{[44,91]}\end{array}$ & $\begin{array}{l}\text { SPS model and } \\
\text { rat model of } \\
\text { post-traumatic } \\
\text { stress disorder } \\
\quad[44,91]\end{array}$ & $\begin{array}{l}\downarrow \text { Anxiety index; } \uparrow \text { Risk assessment; } \downarrow \text { grooming behaviors in } \\
\text { EPMT; } \uparrow \text { total number of line crossings of an open field after } \\
\text { SPS; } \downarrow \text { SPS-induced decreasement in hypothalamic } \\
\text { neuropeptide Y expression; } \uparrow \text { in locus cerulean tyrosine } \\
\text { hydroxylase expression; } \downarrow \text { expression of BDNF }[44,91] .\end{array}$ \\
\hline $\begin{array}{l}\text { Ginsenoside Rb1, Re; } \\
\text { ginsenoside Rh1, PPD }\end{array}$ & $\begin{array}{l}\text { EPM test } \\
{[27,40]}\end{array}$ & $\begin{array}{l}\text { Immobilization } \\
\text { stress-induced } \\
\text { ICR mice } \\
{[27,40]}\end{array}$ & $\begin{array}{l}\uparrow \text { Time spent in open arms and open arm entries in EPM tests; } \\
\downarrow \text { Immobilization stress-induced serum levels of } \\
\text { corticosterone and IL- } 6 \text {; } \downarrow \text { anxiolytic effect via } \\
\gamma \text {-aminobutyrate A (GABA A) receptor(s) }[27,40] \text {. }\end{array}$ \\
\hline Ginsenoside Rg3 & $\begin{array}{c}\text { Two electrode } \\
\text { voltage-clamp } \\
\text { technique } \\
{[86,92]}\end{array}$ & $\begin{array}{l}\text { Xenopus laevis } \\
\text { frogs }[86,92]\end{array}$ & $\begin{array}{l}\downarrow \text { Anxiolytic effect via } \gamma \text {-aminobutyrate A (GABA A) } \\
\text { receptor(s) }[86,92] .\end{array}$ \\
\hline Ginsenoside Re & $\begin{array}{l}\text { FST; EPM; } \\
\text { AAT [44] }\end{array}$ & $\begin{array}{l}\text { Repeated } \\
\text { immobilization } \\
\text { stress-induced } \\
\text { rats [44] }\end{array}$ & $\begin{array}{l}\downarrow \text { Stress-induced behavioral deficits in these behavioral tests; } \\
\downarrow \text { TH expression in LC; } \downarrow \text { mRNA expression of BDNF in the } \\
\text { hippocampus; modulate central noradrenergic system in } \\
\text { rats [44]. }\end{array}$ \\
\hline $\begin{array}{l}\text { Ginsenoside Rg3 and } \\
\text { ginsenoside Rh2 }\end{array}$ & $\begin{array}{l}\text { EPM test } \\
{[27,84]}\end{array}$ & $\begin{array}{l}\text { Male ICR mice } \\
\qquad[27,84]\end{array}$ & $\begin{array}{l}\uparrow \text { Time spent on the open arms and the number of open-arm } \\
\text { entries; antagonize GABA/benzodiazepines }[27,84] \text {. }\end{array}$ \\
\hline $\begin{array}{l}\text { Ginsenoside Rb1, } \\
\text { Rg1, and Ro }\end{array}$ & $\begin{array}{l}\text { EPM test } \\
{[68,84]}\end{array}$ & $\begin{array}{l}\text { Male ICR } \\
\text { albino mice } \\
\quad[68,84]\end{array}$ & $\uparrow$ Both the frequency and duration of open arm entries $[68,84]$. \\
\hline Pseudoginsenoside-F11 & $\begin{array}{l}\text { Light-dark box } \\
\text { test; FST [90] }\end{array}$ & $\begin{array}{l}\text { MA-induced } \\
\text { behavioral and } \\
\text { neurochemical } \\
\text { toxicities in } \\
\text { mice [90] }\end{array}$ & $\begin{array}{l}\downarrow \text { Anxiety-like behavior induced by methamphetamine (MA); } \\
\downarrow \text { MA-induced prolonged latency; } \downarrow \text { the error counts; } \\
\downarrow \text { contents of DOPAC, HVA, and 5-HIAA in the brain of } \\
\text { MA-treated mice; antagonize decreases of DA [90]. }\end{array}$ \\
\hline
\end{tabular}

EPM, elevated plus-maze.

\section{Network Target Analysis}

Based on reported researches of each component above, including ginsenoside $\operatorname{Rg} 1, \operatorname{Rg} 3, \operatorname{Rg} 5$, $\mathrm{Rb} 1, \mathrm{Rb3}, \mathrm{Re}, \mathrm{Rh} 1, \mathrm{Rh} 2, \mathrm{Ro}$, pseudoginsenoside-F(11), ginsenoside $\mathrm{K}$, and notoginsenoside $\mathrm{R} 1$, the structures and target properties of 12 active ingredients among them was obtained from the PubChem database (https:/ / pubchem.ncbi.nlm.nih.gov/), shown as Table 3; then network targets of antidepressant, anxiolytic actions, or other pharmacological effects were analyzed with network pharmacology tools. In the present work, an integrated in silico approach was introduced to identify the target proteins for the active ingredients of Panax notoginseng (Burk) F. H. Chen (Table 3). Predictive models were used, including STITCH (http:/ / stitch.embl.de/) and Swiss Target Prediction (http:/ / www.swisstargetprediction.ch/), and databases were mined including Herbal Ingredients' Targets database (http:/ / lifecenter.sgst.cn/hit/) [93,94]. Finally, targets related to antidepressant or anxiolytic effects and other effects were determined, interacting with the selected 12 active ingredients of Panax notoginseng (Burk) F. H. Chen (Table 4).

Main predicted network targets of Panax notoginseng (Burk) F. H. Chen were shown in Table 4 and Figure 1. Twenty-six targets were identified for 12 active ingredients of Panax notoginseng (Burk) F. H. Chen with 87 interactions. The more link lines between compounds and predicted protein targets, the greater the linear density, indicating that they are more likely to interact, but specific experiments are needed to confirm. This is shown in Figure 1. 
Based on the scores (Table 4), multiple therapeutic targets concerning central nervous system were mediated by the active ingredients of Panax notoginseng (Burk) F. H. Chen, such as BAK1, BCL2, BCL2A1, JUN, MAPK8, AKT1, NFKB1, TP53, and APAF1. Most of these targets are mainly involved in apoptosis and inflammation of vascular and central neural systems. Figures 1 and 2 show that BCL2-A1, BCL2, NF-kappa-B, and TP53 was predicted to have strong association actions of compound and predicted target network of Panax notoginseng (Burk) F. H. Chen, indicating that Notoginseng saponins may exert anti-depression and anti-anxiety effects through inflammatory regulation and anti-apoptotic pathway.

BCL2 suppresses apoptosis in a variety of cell systems, including neural cells and factor-dependent lymphohematopoietic, and regulates cell death by controlling the mitochondrial membrane permeability by binding to the apoptosis-activating factor (APAF-1). NF-kappa-B is a pleiotropic transcription factor present in almost all cell types, and is the endpoint of a series of signal transduction events that are initiated by a vast array of stimuli related to many biological processes, such as inflammation, immunity, differentiation, cell growth, tumorigenesis, and apoptosis. TP53 acts as a tumor suppressor in many tumor types, and induces growth arrest or apoptosis depending on the physiological circumstances and cell type, involved in cell cycle regulation as a trans-activator that acts to negatively regulate cell division by controlling a set of genes required for this process. These indicate that PNS may have anti-inflammatory and anti-apoptotic effects, which leads to the preservation of brain nerves, and regulate the activity and secretion of nerve cells, exerting anti-depression and anxiolytic effects, which may provide new directions for further in-depth researches of related mechanisms.

Table 3. Active ingredients of Panax notoginseng saponins.

No. Name


Table 3. Cont.

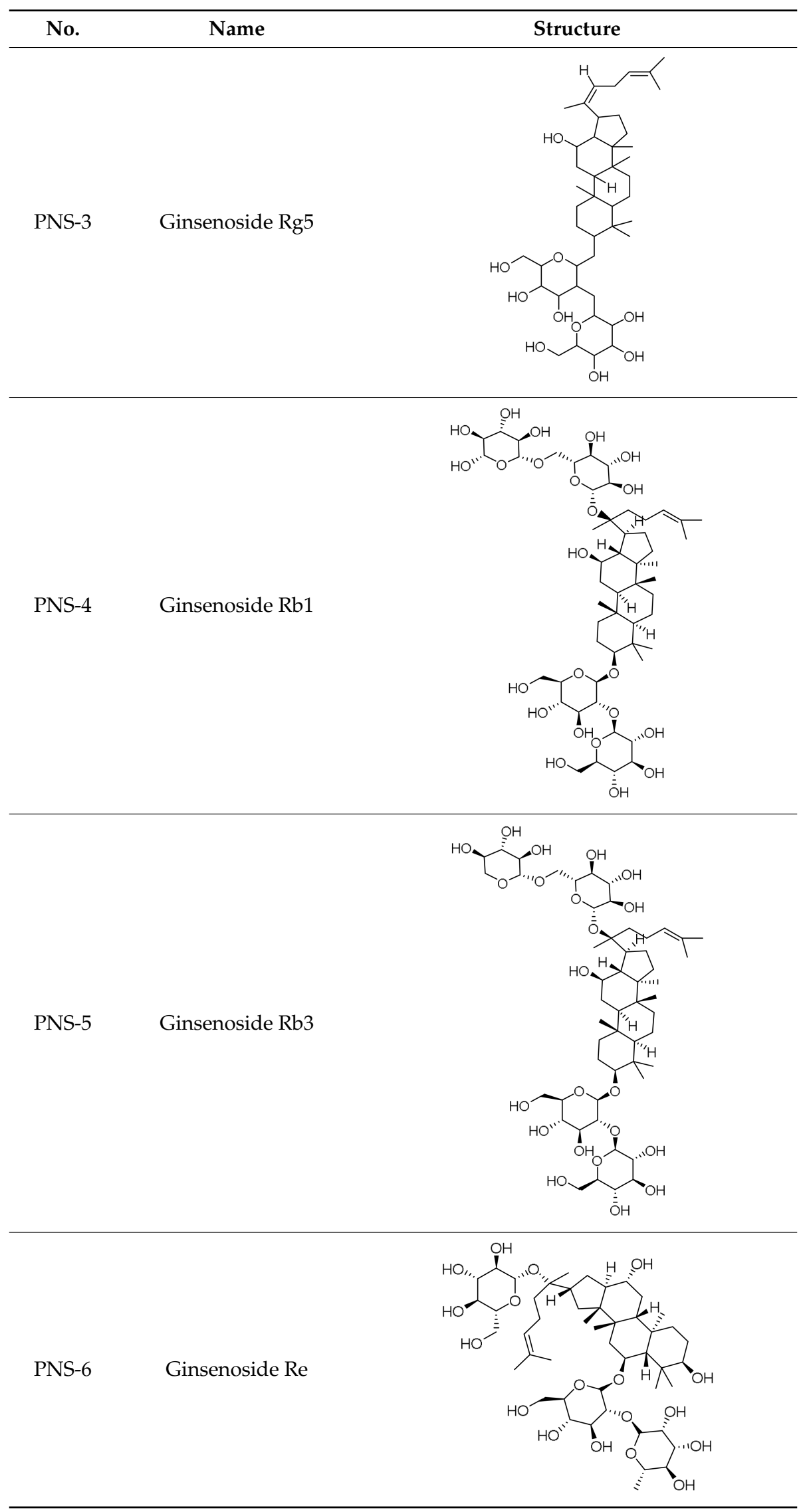


Table 3. Cont.

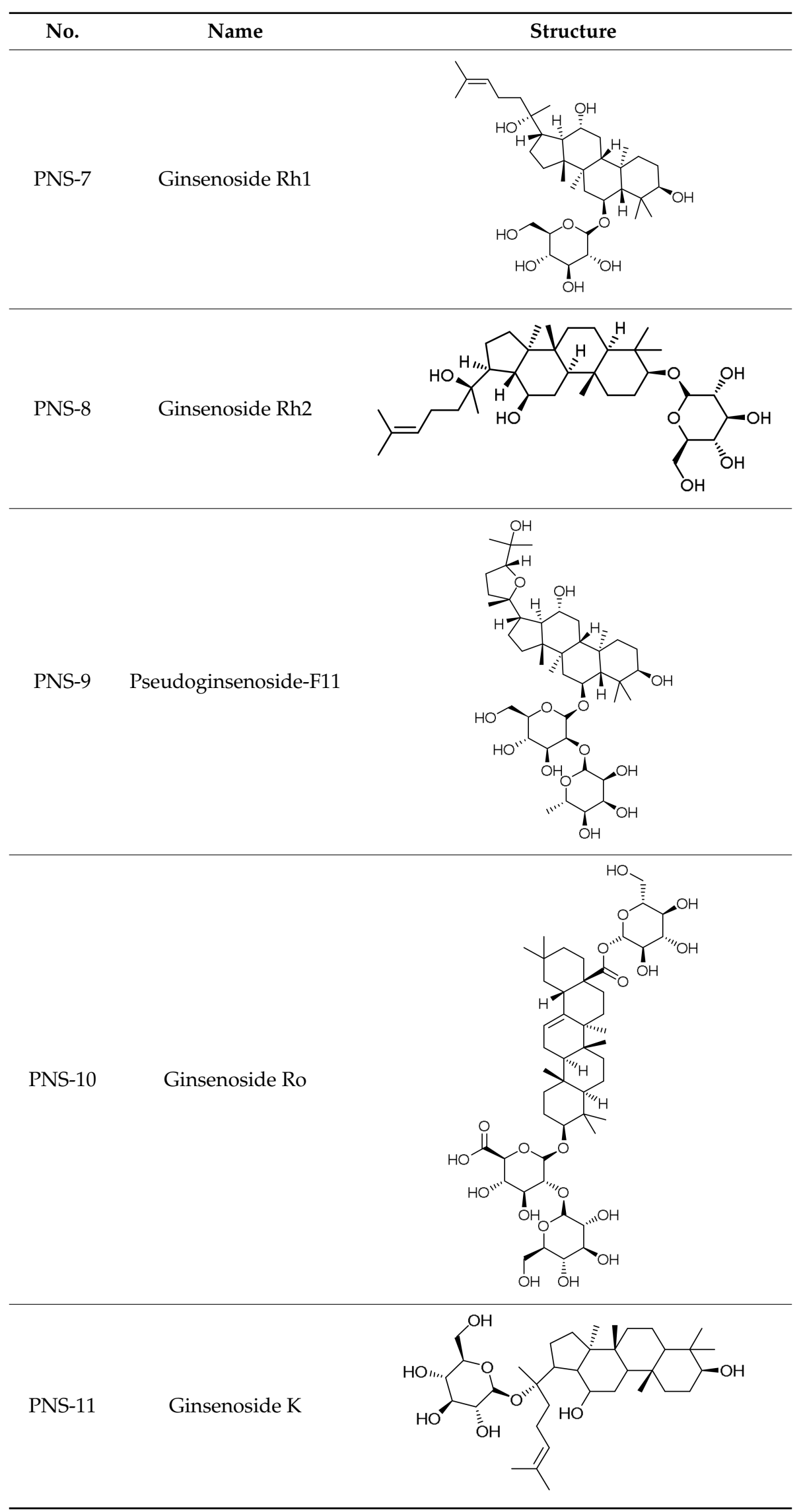


Table 3. Cont.

No. Name

Table 4. Main predicted target information of Panax notoginseng (Burk) F. H. Chen.

\begin{tabular}{ccccc}
\hline Node1 & Node2 & Node1 Accession & Node2 Accession & Score \\
\hline APAF1 & BAK1 & ENSP00000448165 & ENSP00000353878 & 0.997 \\
APAF1 & BCL2 & ENSP00000448165 & ENSP00000329623 & 0.999 \\
APAF1 & BCL2A1 & ENSP00000448165 & ENSP00000267953 & 0.912 \\
APAF1 & BIK & ENSP00000448165 & ENSP00000216115 & 0.932 \\
APAF1 & JUN & ENSP00000448165 & ENSP00000360266 & 0.582 \\
APAF1 & MAPK8 & ENSP00000448165 & ENSP00000353483 & 0.611 \\
APAF1 & MCL1 & ENSP00000448165 & ENSP00000358022 & 0.95 \\
APAF1 & NFKB1 & ENSP00000448165 & ENSP00000226574 & 0.608 \\
APAF1 & TP53 & ENSP00000448165 & ENSP00000269305 & 0.996 \\
BAK1 & APAF1 & ENSP00000353878 & ENSP00000448165 & 0.997 \\
BAK1 & BBC3 & ENSP00000353878 & ENSP00000404503 & 0.414 \\
BAK1 & BCL2 & ENSP00000353878 & ENSP00000329623 & 0.999 \\
BAK1 & BCL2A1 & ENSP00000353878 & ENSP00000267953 & 0.987 \\
BAK1 & BIK & ENSP00000353878 & ENSP00000216115 & 0.583 \\
BAK1 & JUN & ENSP00000353878 & ENSP00000360266 & 0.852 \\
BAK1 & JUNB & ENSP00000353878 & ENSP00000303315 & 0.658 \\
BAK1 & JUND & ENSP00000353878 & ENSP00000252818 & 0.671 \\
BAK1 & MAPK8 & ENSP00000353878 & ENSP00000353483 & 0.83 \\
BAK1 & MCL1 & ENSP00000353878 & ENSP00000358022 & 0.99 \\
\hline
\end{tabular}




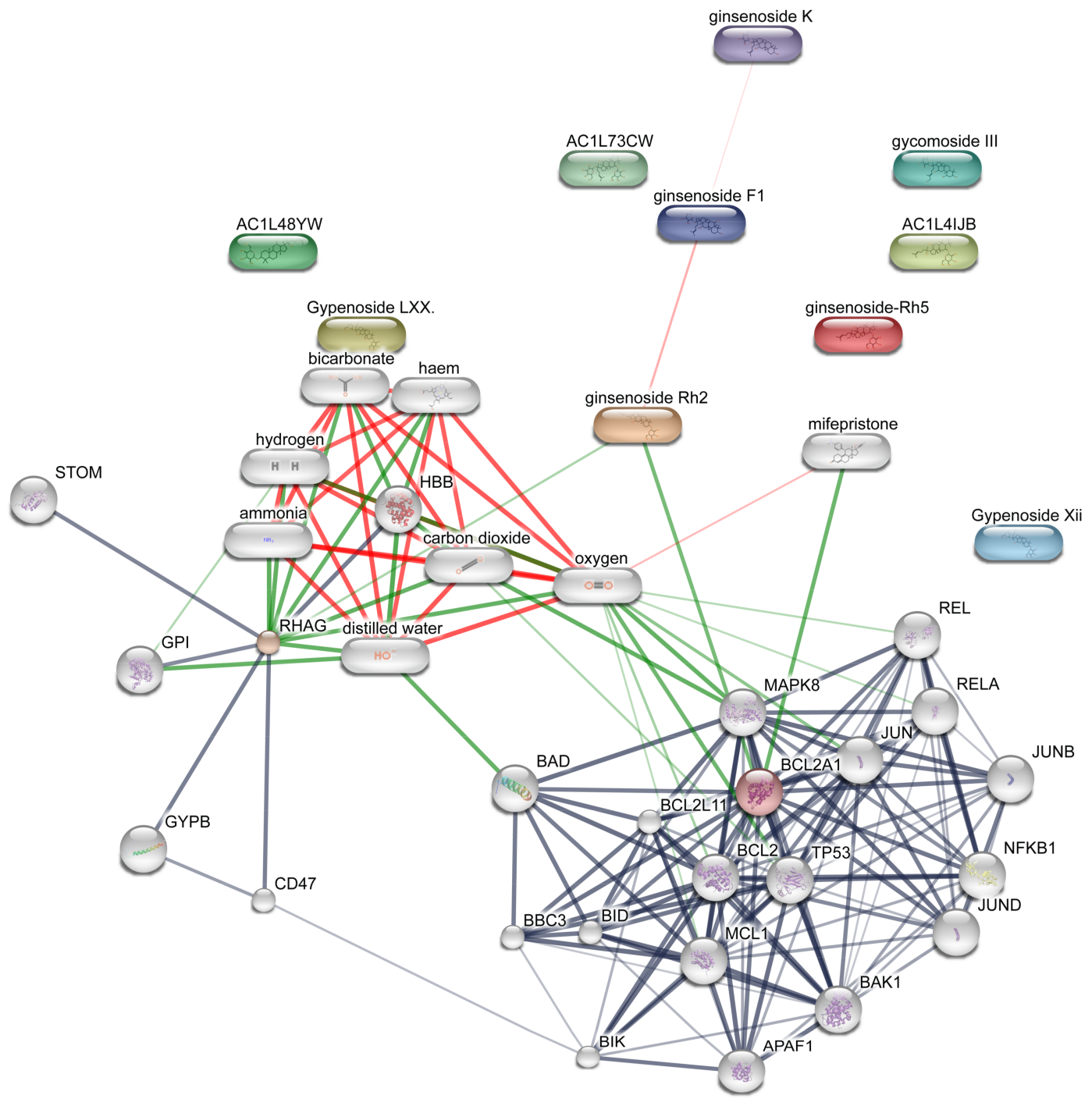

Figure 1. Compound-target network of Panax notoginseng (Burk) F. H. Chen. Edges represent protein-protein associations; protein-protein interactions are shown in grey, chemical-protein interactions in green, and interactions between chemicals in red; stronger associations are represented by thicker lines. Small nodes: protein of unknown 3D structure; large nodes: some 3D structure is known or predicted; colored nodes: query proteins and first shell of interactors; white nodes: second shell of interactors. The chemical groups and structures in the gray rectangles, such as carbon dioxide, oxygen, and HO-, suggest functional links and predictions for specific actions on with potentially acting protein targets and combined scores of predicted interactions presented by analysing the Experimental/Biochemical Data, Association in Curated Databases and Co-Mentioned in PubMed Abstracts, which illustrated the possibility of interaction between compounds and potential protein targets. Associations are meant to be specific and meaningful, i.e., Proteins jointly contribute to a shared function; this does not necessarily mean they are physically binding each other. Predicted models were constructed by STITCH, Swiss Target Prediction, and Herbal Ingredients' Targets database. 

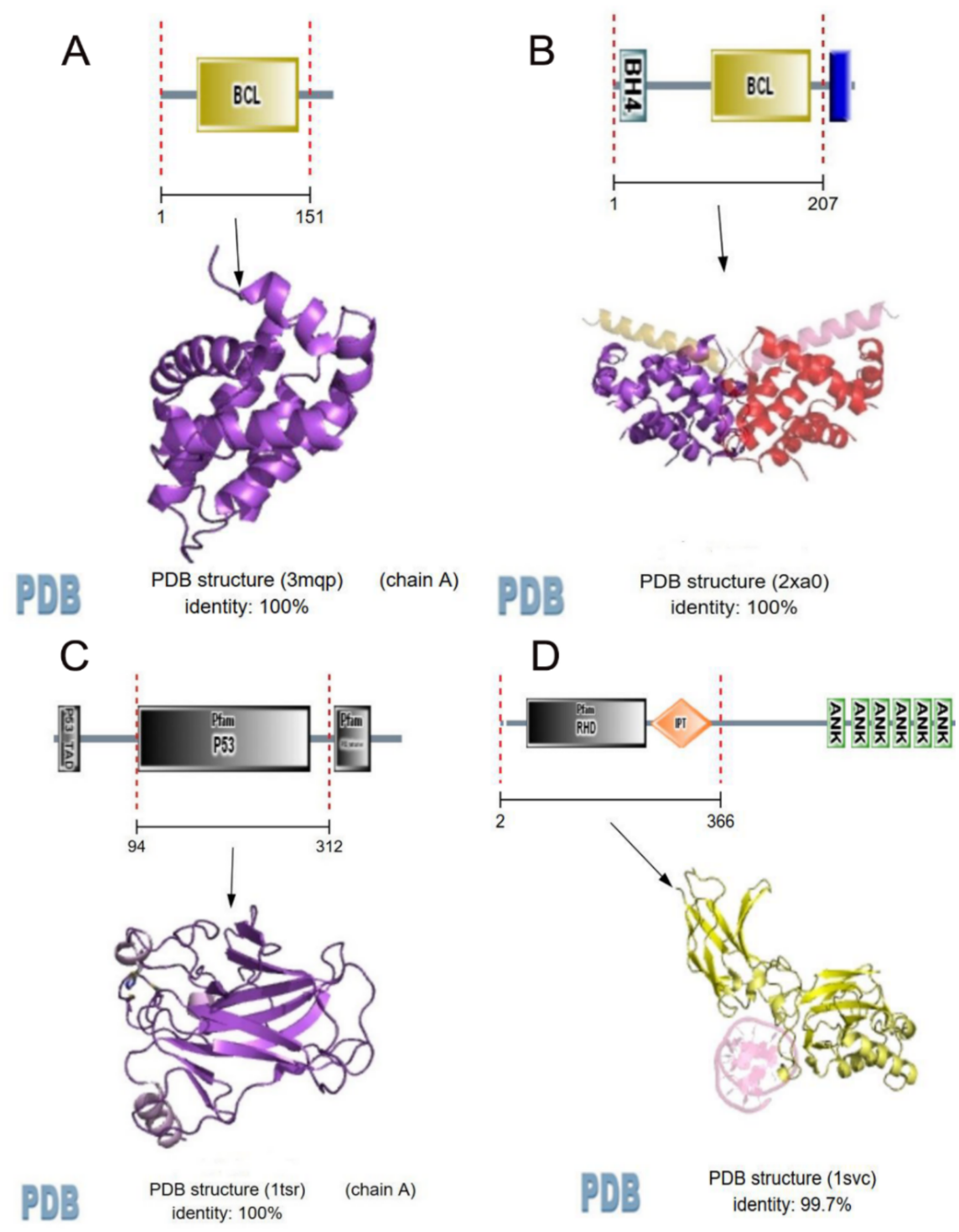

Figure 2. Strong association actions of compound and predicted target network of Panax notoginseng (Burk) F. H. Chen. (A) represents re-center network or functional domain of compounds associated with BCL2-A1; (B) represents BCL2; (C) represents TP53; (D) represents NFKB1; BCL2-A1, BCL2, NF-kappa-B, and TP53 were predicted to have strong association actions of compound and predicted target network of Panax notoginseng (Burk) F. H. Chen, indicating that PNS may exert anti-depression and anti-anxiety effects through inflammatory regulation and anti-apoptotic pathway. Association action models were constructed by STITCH and PDB database.

\section{Conclusions}

Depression is becoming the world's fourth-largest disease, and may become the second-largest disease in 2020, second only to cardiac disease. Antidepressants can be divided into four categories: tricyclic, tetracyclic, monoamine oxidase inhibitors, and other new antidepressants, and sometimes can cause addiction or undesirable side effects. Therefore, new drugs or treatment methods are required. Future studies should consider investigating alternatives to conventional drugs or Chinese medicinal plants. These have been used for more than a thousand years with generally carry a low risk of negative side effects. Panax notoginseng (Burk) F. H. Chen, as traditional Chinese medicine has a long history of high clinical value, such as anti-inflammatory [16,20,31,32], anti-oxidation, inhibition of platelet aggregation, regulation of blood glucose [27,33,34] and blood pressure [35-37], inhibition 
of neuronal apoptosis [14,38,39], and neuronal protection. Currently, Panax notoginseng (Burk) F. H. Chen may improve mental function, have anti-insomnia and anti-depression effects, alleviate anxiety, and decrease neural network excitation $[25,26]$.

As outlined above, we have confirmed that PNS, ginsenoside Rg1, ginsenoside Rb1, ginsenosidenRg3, ginsenoside Rh2, ginsenoside Rg5, $\mathrm{K}$, and ginsenoside Re have antidepressant or anxiolytic effects, and ginsenoside Rhland pseudoginsenoside-F(11) have anxiolytic effects. These components may exert these effects through regulating neurotransmitter mechanism (5-HT, DA, NE), modulation of the gamma-amino butyric acid (GABA) neurotransmission, glutamatergic system, hypo-thalamus-pituitary-adrenal (HPA) axis, brain-derived neurotrophic factor (BDNF), and its intracellular signaling pathways in the central nervous system; and produce neuronal protection by anti-inflammatory, anti-oxidation, inhibition of neuronal apoptosis, or platelet aggregation and its intracellular signaling pathways.

Although, among them, some compounds have been only proved to have antidepressant or anxiolytic effects in GTS [95], the main chemical composition of Panax notoginseng (Burk) F. H. Chen is similar to that of ginseng; at present, less researches have been shown on the role of Panax notoginseng (Burk) F. H. Chen and chemical composition in anti-anxiety and anti-depression. Therefore, as a potential new drug, a systematic and in-depth study of the effects and its molecular mechanisms of anti-anxiety and anti-depression of Panax notoginseng (Burk) F. H. Chen is needed.

Further work on elucidation of the structure-function relationship among saponins, understanding of multi-target network pharmacology of Panax notoginseng (Burk) F. H. Chen with Network Pharmacology tools, as well as developing its new clinical usage and comprehensive utilize will enhance the therapeutic potentials of Panax notoginseng (Burk) F. H. Chen. A clearer understanding of the mechanisms underlying the effects of Panax notoginseng (Burk) F. H. Chen on human cytokine/metabolic systems and on stress-induced hormonal changes could facilitate the development of a wide range of treatments for patients with psychological and physical diseases.

Acknowledgments: This work was supported by the Major Scientific and Technological Special Project for "Significant New Drugs Formulation" (No. 2017ZX09101003-009), the Chinese Academy of Medical Sciences (CAMS) Innovation Fund for Medical Sciences (No. 2016-I2M-1-012), the CAMS Initiative for Innovative Medicine (No. CAMS-I2M-1-010), the Special Research Project for TCM (No. 201507004), the National Natural Science Foundation of China (No. 81503290), and The National Natural Science Foundation of China (NO. 81773938).

Conflicts of Interest: The authors declare no conflicts of interest.

\section{References}

1. Dean, J.; Keshavan, M. The neurobiology of depression: An integrated view. Asian J. Psychiatry 2017, 27, 101-111. [CrossRef] [PubMed]

2. Dell'Osso, L.; Carmassi, C.; Mucci, F.; Marazziti, D. Depression, Serotonin and Tryptophan. Curr. Pharm. Des. 2016, 22, 949-954. [CrossRef] [PubMed]

3. Dunn, E.C.; Brown, R.C.; Dai, Y.; Rosand, J.; Nugent, N.R.; Amstadter, A.B.; Smoller, J.W. Genetic determinants of depression: Recent findings and future directions. Harv. Rev. Psychiatry 2015, 23, 1-18. [CrossRef] [PubMed]

4. Hashmi, A.M.; Butt, Z.; Umair, M. Is depression an inflammatory condition? A review of available evidence. J. Pak. Med. Assoc. 2013, 63, 899-906. [PubMed]

5. Catena-Dell'Osso, M.; Caserta, A.; Baroni, S.; Nisita, C.; Marazziti, D. The relationship between epilepsy and depression: An update. Curr. Med. Chem. 2013, 20, 2861-2867. [PubMed]

6. Limon, A.; Mamdani, F.; Hjelm, B.E.; Vawter, M.P.; Sequeira, A. Targets of polyamine dysregulation in major depression and suicide: Activity-dependent feedback, excitability, and neurotransmission. Neurosci. Biobehav. Rev. 2016, 66, 80-91. [CrossRef] [PubMed]

7. Novais, F.; Starkstein, S. Phenomenology of Depression in Alzheimer's Disease. J. Alzheimers Dis. 2015, 47, 845-855. [CrossRef] [PubMed]

8. Stepanichev, M.; Dygalo, N.N.; Grigoryan, G.; Shishkina, G.T.; Gulyaeva, N. Rodent models of depression: Neurotrophic and neuroinflammatory biomarkers. BioMed Res. Int. 2014, 2014, 932757. [CrossRef] [PubMed] 
9. Uchida, S.; Yamagata, H.; Seki, T.; Watanabe, Y. Epigenetic mechanisms of major depression: Targeting neuronal plasticity. Psychiatry Clin. Neurosci. 2017. [CrossRef] [PubMed]

10. Zheng, X.; Ma, S.; Kang, A.; Wu, M.; Wang, L.; Wang, Q.; Wang, G.; Hao, H. Chemical dampening of Ly6C(hi) monocytes in the periphery produces anti-depressant effects in mice. Sci. Rep. 2016, 6, 19406. [CrossRef] [PubMed]

11. Zong, S.; Hoffmann, C.; Mane-Damas, M.; Molenaar, P.; Losen, M.; Martinez, P. Neuronal Surface Autoantibodies in Neuropsychiatric Disorders: Are There Implications for Depression? Front. Immunol. 2017, 8, 752. [CrossRef] [PubMed]

12. Chi, S.; Yu, J.T.; Tan, M.S.; Tan, L. Depression in Alzheimer's disease: Epidemiology, mechanisms, and management. J. Alzheimers Dis. 2014, 42, 739-755. [PubMed]

13. Flaster, M.; Sharma, A.; Rao, M. Poststroke depression: A review emphasizing the role of prophylactic treatment and synergy with treatment for motor recovery. Top. Stroke Rehabil. 2013, 20, 139-150. [CrossRef] [PubMed]

14. Li, W.; Ling, S.; Yang, Y.; Hu, Z.; Davies, H.; Fang, M. Systematic hypothesis for post-stroke depression caused inflammation and neurotransmission and resultant on possible treatments. Neuro Endocrinol. Lett. 2014, 35, 104-109. [PubMed]

15. Benson, C.; Mifflin, K.; Kerr, B.; Jesudasan, S.J.; Dursun, S.; Baker, G. Biogenic Amines and the Amino Acids GABA and Glutamate: Relationships with Pain and Depression. Mod. Trends Pharmacopsychiatry 2015, 30, 67-79. [PubMed]

16. Jeon, S.W.; Kim, Y.K. Neuroinflammation and cytokine abnormality in major depression: Cause or consequence in that illness? World J. Psychiatry 2016, 6, 283-293. [CrossRef] [PubMed]

17. Oakes, P.; Loukas, M.; Oskouian, R.J.; Tubbs, R.S. The neuroanatomy of depression: A review. Clin. Anat. 2017, 30, 44-49. [CrossRef] [PubMed]

18. Lin, F.B.; Hou, D.R.; Tang, Q.P. Research progress of depression and the application of esketamine. J. South. Med. Univ. 2016, 37, 567.

19. Zhang, H.; Zhou, Z.; Chen, Z.; Zhong, Z.; Li, Z. Ginsenoside Rg3 exerts anti-depressive effect on an NMDA-treated cell model and a chronic mild stress animal model. J. Pharmacol. Sci. 2017, 134, 45-54. [CrossRef] [PubMed]

20. Allison, D.J.; Ditor, D.S. The common inflammatory etiology of depression and cognitive impairment: A therapeutic target. J. Neuroinflamm. 2014, 11, 151. [CrossRef] [PubMed]

21. Anderson, G.; Maes, M. Neurodegeneration in Parkinson's disease: Interactions of oxidative stress, tryptophan catabolites and depression with mitochondria and sirtuins. Mol. Neurobiol. 2014, 49, 771-783. [CrossRef] [PubMed]

22. Anderson, G.; Maes, M. TRYCAT pathways link peripheral inflammation, nicotine, somatization and depression in the etiology and course of Parkinson's disease. CNS Neurol. Disord. Drug Targets 2014, 13, 137-149. [CrossRef]

23. Anderson, G.; Seo, M.; Berk, M.; Carvalho, A.F.; Maes, M. Gut Permeability and Microbiota in Parkinson's Disease: Role of Depression, Tryptophan Catabolites, Oxidative and Nitrosative Stress and Melatonergic Pathways. Curr. Pharm. Des. 2016, 22, 6142-6151. [CrossRef] [PubMed]

24. Braga, J.; Campar, A. Biological causes of depression in Systemic Lupus Erythematosus. Acta Reumatol. Port. 2014, 39, 218-226. [PubMed]

25. Cui, J.; Jiang, L.; Xiang, H. Ginsenoside Rb3 exerts antidepressant-like effects in several animal models. J. Psychopharmacol. 2012, 26, 697-713. [CrossRef] [PubMed]

26. Xiang, H.; Liu, Y.; Zhang, B.; Huang, J.; Li, Y.; Yang, B.; Huang, Z.; Xiang, F.; Zhang, H. The antidepressant effects and mechanism of action of total saponins from the caudexes and leaves of Panax notoginseng in animal models of depression. Phytomedicine 2011, 18, 731-738. [CrossRef] [PubMed]

27. Zhang, H.; Li, Z.; Zhou, Z.; Yang, H.; Zhong, Z.; Lou, C. Antidepressant-like effects of ginsenosides: A comparison of ginsenoside $\mathrm{Rb} 3$ and its four deglycosylated derivatives, $\mathrm{Rg} 3, \mathrm{Rh} 2, \mathrm{~K}$, and 20(S)-protopanaxadiol in mice models of despair. Pharmacol. Biochem. Behav. 2016, 140, 17-26. [CrossRef] [PubMed]

28. Su, P.; Wang, L.; Du, S.J.; Xin, W.F.; Zhang, W.S. Advance in studies of Panax notoginseng saponins on pharmacological mechanism of nervous system disease. Zhongguo Zhong Yao Za Zhi 2014, 39, 4516-4521. [PubMed] 
29. Bahramsoltani, R.; Farzaei, M.H.; Farahani, M.S.; Rahimi, R. Phytochemical constituents as future antidepressants: A comprehensive review. Rev. Neurosci. 2015, 26, 699-719. [CrossRef] [PubMed]

30. Wang, T.; Guo, R.; Zhou, G.; Zhou, X.; Kou, Z.; Sui, F.; Li, C.; Tang, L.; Wang, Z. Traditional uses, botany, phytochemistry, pharmacology and toxicology of Panax notoginseng (Burk.) F.H. Chen: A review. J. Ethnopharmacol. 2016, 188, 234-258. [CrossRef] [PubMed]

31. Zhang, J.; Ding, L.; Wang, B.; Ren, G.; Sun, A.; Deng, C.; Wei, X.; Mani, S.; Wang, Z.; Dou, W. Notoginsenoside $\mathrm{R} 1$ attenuates experimental inflammatory bowel disease via pregnane $\mathrm{X}$ receptor activation. J. Pharmacol. Exp. Ther. 2015, 352, 315-324. [CrossRef] [PubMed]

32. Zheng, X.; Liang, Y.; Kang, A.; Ma, S.J.; Xing, L.; Zhou, Y.Y.; Dai, C.; Xie, H.; Xie, L.; Wang, G.J.; et al. Peripheral immunomodulation with ginsenoside $\mathrm{Rg} 1$ ameliorates neuroinflammation-induced behavioral deficits in rats. Neuroscience 2014, 256, 210-222. [CrossRef] [PubMed]

33. Kim, N.H.; Kim, K.Y.; Jeong, H.J.; Kim, H.M. Antidepressant-like effect of altered Korean red ginseng in mice. Behav. Med. 2011, 37, 42-46. [CrossRef] [PubMed]

34. Xie, T.; Zhou, X.P.; Lin, L.L.; Xu, J.Y.; Shen, C.S.; Feng, Z.; Zhou, L.L.; Shan, J.J. Metabolomics analysis of Tripterygium wilfordii formulation based on theory of detoxicity compatibility. Zhongguo Zhong Yao Za Zhi 2016, 41, 1124-1129. [PubMed]

35. Pang, H.H.; Li, M.Y.; Wang, Y.; Tang, M.K.; Ma, C.H.; Huang, J.M. Effect of compatible herbs on the pharmacokinetics of effective components of Panax notoginseng in Fufang Xueshuantong Capsule. J. Zhejiang Univ. Sci. B 2017, 18, 343-352. [CrossRef] [PubMed]

36. Tian, Z.; Pang, H.; Du, S.; Lu, Y.; Zhang, L.; Wu, H.; Guo, S.; Wang, M.; Zhang, Q. Effect of Panax notoginseng saponins on the pharmacokinetics of aspirin in rats. J. Chromatogr. B 2017, 1040, 136-143. [CrossRef] [PubMed]

37. Zhao, S.; Zheng, M.X.; Chen, H.E.; Wu, C.Y.; Wang, W.T. Effect of panax notoginseng saponins injection on the p38MAPK pathway in lung tissue in a rat model of hypoxic pulmonary hypertension. Chin. J. Integr. Med. 2015, 21, 147-151. [CrossRef] [PubMed]

38. Hou, Q.L.; Wang, Y.; Li, Y.B.; Hu, X.L.; Wang, S.L. Protective effect of notoginsenoside R1 on neuron injury induced by OGD/R through ATF6/Akt signaling pathway. Zhongguo Zhong Yao Za Zhi 2017, 42, 1167-1174. [PubMed]

39. Yang, X.; Yang, S.; Hong, C.; Yu, W.; Guonian, W. Panax Notoginseng Saponins attenuates sevofluraneinduced nerve cell injury by modulating AKT signaling pathway. Mol. Med. Rep. 2017, 16, 7829-7834. [CrossRef] [PubMed]

40. Oh, H.A.; Kim, D.-E.; Choi, H.J.; Kim, N.J.; Kim, D.-H. Anti-stress Effects of 20(S)-Protopanaxadiol and 20(S)-Protopanaxatriol in Immobilized Mice. Biol. Pharm. Bull. 2015, 38, 331-335. [CrossRef] [PubMed]

41. Albert, P.R.; Fiori, L.M. Transcriptional dys-regulation in anxiety and major depression: 5-HT1A gene promoter architecture as a therapeutic opportunity. Curr. Pharm Des. 2014, 20, 3738-3750. [CrossRef] [PubMed]

42. Liu, M.Y.; Zhang, L.J.; Liu, M.C. Effect of ginsenoside pre-treatment on 5-hydroxytryptamine system in SD rats with myocardial infarction and depression. Zhonghua Nei Ke Za Zhi 2016, 55, 700-704. [PubMed]

43. Jiang, B.; Xiong, Z.; Yang, J.; Wang, W.; Wang, Y.; Hu, Z.L.; Wang, F.; Chen, J.G. Antidepressant-like effects of ginsenoside $\operatorname{Rg} 1$ are due to activation of the BDNF signalling pathway and neurogenesis in the hippocampus. Br. J. Pharmacol. 2012, 166, 1872-1887. [CrossRef] [PubMed]

44. Lee, B.; Shim, I.; Lee, H.; Hahm, D.H. Effect of ginsenoside Re on depression- and anxiety-like behaviors and cognition memory deficit induced by repeated immobilization in rats. J. Microbiol. Biotechnol. 2012, 22, 708-720. [CrossRef] [PubMed]

45. Liu, Z.; Qi, Y.; Cheng, Z.; Zhu, X.; Fan, C.; Yu, S.Y. The effects of ginsenoside Rg1 on chronic stress induced depression-like behaviors, BDNF expression and the phosphorylation of PKA and CREB in rats. Neuroscience 2016, 322, 358-369. [CrossRef] [PubMed]

46. Si, Y.; Zhu, J.; Huang, X.; Zhu, P.; Xie, C. Effects of Panax notoginseng saponins on proliferation and differentiation of rat embryonic cortical neural stem cells. J. Chin. Med. Assoc. 2016, 79, 256-263. [CrossRef] [PubMed]

47. Zhao, M.; Chen, L.; Yang, J.; Han, D.; Fang, D.; Qiu, X.; Yang, X.; Qiao, Z.; Ma, J.; Wang, L.; et al. BDNF Val66Met polymorphism, life stress and depression: A meta-analysis of gene-environment interaction. J. Affect. Disord. 2017, 227, 226-235. [CrossRef] [PubMed] 
48. Anderson, G.; Berk, M.; Dean, O.; Moylan, S.; Maes, M. Role of immune-inflammatory and oxidative and nitrosative stress pathways in the etiology of depression: therapeutic implications. CNS Drugs 2014, 28, 1-10. [CrossRef] [PubMed]

49. Anderson, G.; Maes, M.; Berk, M. Schizophrenia is primed for an increased expression of depression through activation of immuno-inflammatory, oxidative and nitrosative stress, and tryptophan catabolite pathways. Prog. Neuropsychopharm. Biol. Psychiatry 2013, 42, 101-114. [CrossRef] [PubMed]

50. Choi, J.G.; Jin, Y.H.; Lee, H.; Oh, T.W.; Yim, N.H.; Cho, W.K.; Ma, J.Y. Protective Effect of Panax notoginseng Root Water Extract against Influenza A Virus Infection by Enhancing Antiviral Interferon-Mediated Immune Responses and Natural Killer Cell Activity. Front. Immunol. 2017, 8, 1542. [CrossRef] [PubMed]

51. Han, J.Y.; Li, Q.; Ma, Z.Z.; Fan, J.Y. Effects and mechanisms of compound Chinese medicine and major ingredients on microcirculatory dysfunction and organ injury induced by ischemia/reperfusion. Pharmacol. Ther. 2017, 177, 146-173. [CrossRef] [PubMed]

52. Kang, A.; Hao, H.; Zheng, X.; Liang, Y.; Xie, Y.; Xie, T.; Dai, C.; Zhao, Q.; Wu, X.; Xie, L.; et al. Peripheral anti-inflammatory effects explain the ginsenosides paradox between poor brain distribution and anti-depression efficacy. J. Neuroinflamm. 2011, 8, 100. [CrossRef] [PubMed]

53. Kang, A.; Xie, T.; Zhu, D.; Shan, J.; Di, L.; Zheng, X. Suppressive Effect of Ginsenoside Rg3 against Lipopolysaccharide-Induced Depression-Like Behavior and Neuroinflammation in Mice. J. Agric. Food Chem. 2017, 65, 6861-6869. [CrossRef] [PubMed]

54. Pan, L.; Zhang, Y.; Lu, J.; Geng, Z.; Jia, L.; Rong, X.; Wang, Z.; Zhao, Q.; Wu, R.; Chu, M.; et al. Panax Notoginseng Saponins Ameliorates Coxsackievirus B3-Induced Myocarditis by Activating the Cystathionine-gamma-Lyase/Hydrogen Sulfide Pathway. J. Cardiovasc. Transl. Res. 2015, 8, 536-544. [CrossRef] [PubMed]

55. Wang, J.; Lu, L.; Wang, Y.; Wu, Y.; Han, J.; Wang, W.; Li, C.; Tu, P. Qishenyiqi Dropping Pill attenuates myocardial fibrosis in rats by inhibiting RAAS-mediated arachidonic acid inflammation. J. Ethnopharmacol. 2015, 176, 375-384. [CrossRef] [PubMed]

56. Wenxi, D.; Shufang, D.; Xiaoling, Y.; Liming, Y. Panax notoginseng saponins suppress radiation-induced osteoporosis by regulating bone formation and resorption. Phytomedicine 2015, 22, 813-819. [CrossRef] [PubMed]

57. Wu, J.X.; Chen, J.X. Negative chronotropic and inotropic effects of Panax notoginseng saponins. Zhongguo Yao Li Xue Bao 1988, 9, 409-412. [PubMed]

58. Ge, Z.R.; Xu, M.C.; Huang, Y.U.; Zhang, C.J.; Lin, J.E.; Ruan, C.W. Cardioprotective effect of notoginsenoside $\mathrm{R} 1$ in a rabbit lung remote ischemic postconditioning model via activation of the TGF-beta1/TAK1 signaling pathway. Exp. Ther. Med. 2016, 11, 2341-2348. [CrossRef] [PubMed]

59. Wang, T.; Wan, D.; Shao, L.; Dai, J.; Jiang, C. Notoginsenoside R1 stimulates osteogenic function in primary osteoblasts via estrogen receptor signaling. Biochem. Biophys. Res. Commun. 2015, 466, 232-239. [CrossRef] [PubMed]

60. Wang, Y.; Ren, Y.; Xing, L.; Dai, X.; Liu, S.; Yu, B.; Wang, Y. Endothelium-dependent vasodilation effects of Panax notoginseng and its main components are mediated by nitric oxide and cyclooxygenase pathways. Exp. Ther. Med. 2016, 12, 3998-4006. [CrossRef] [PubMed]

61. Xu, Y.; Lin, L.; Tang, L.; Zheng, M.; Ma, Y.; Huang, L.; Meng, W.; Wang, W. Notoginsenoside R1 attenuates hypoxia and hypercapnia-induced vasoconstriction in isolated rat pulmonary arterial rings by reducing the expression of ERK. Am. J. Chin. Med. 2014, 42, 799-816. [CrossRef] [PubMed]

62. Luo, J.; Min, S.; Wei, K.; Zhang, J.; Liu, Y. Propofol interacts with stimulus intensities of electroconvulsive shock to regulate behavior and hippocampal BDNF in a rat model of depression. Psychiatry Res. 2012, 198, 300-306. [CrossRef] [PubMed]

63. Gazal, M.; Ortmann, C.F.; Martins, F.A.; Streck, E.L.; Quevedo, J.; de Campos, A.M.; Stefanello, F.M.; Kaster, M.P.; Ghisleni, G.; Reginatto, F.H.; et al. Antidepressant-like effects of aqueous extract from Cecropia pachystachya leaves in a mouse model of chronic unpredictable stress. Brain Res. Bull. 2014, 108, 10-17. [CrossRef] [PubMed]

64. Pechlivanova, D.; Tchekalarova, J.; Nikolov, R.; Yakimova, K. Dose-dependent effects of caffeine on behavior and thermoregulation in a chronic unpredictable stress model of depression in rats. Behav. Brain Res. 2010, 209, 205-211. [CrossRef] [PubMed] 
65. Taksande, B.G.; Faldu, D.S.; Dixit, M.P.; Sakaria, J.N.; Aglawe, M.M.; Umekar, M.J.; Kotagale, N.R. Agmatine attenuates chronic unpredictable mild stress induced behavioral alteration in mice. Eur. J. Pharmacol. 2013, 720, 115-120. [CrossRef] [PubMed]

66. Shi, M.; Wang, J.Y.; Luo, F. Depression shows divergent effects on evoked and spontaneous pain behaviors in rats. J. Pain 2010, 11, 219-229. [CrossRef] [PubMed]

67. Wu, H.F.; Zhu, C.H.; Guo, J.Y. Effect of ginsenoside Rg1 on behaviors and hippocampal amino acids in depressive-like rats. Zhongguo Zhong Yao Za Zhi 2012, 37, 3117-3121. [PubMed]

68. Carr, M.N.; Bekku, N.; Yoshimura, H. Identification of anxiolytic ingredients in ginseng root using the elevated plus-maze test in mice. Eur. J. Pharmacol. 2006, 531, 160-165. [CrossRef] [PubMed]

69. Cha, H.Y.; Park, J.H.; Hong, J.T.; Yoo, H.S.; Song, S.; Hwang, B.Y.; Eun, J.S.; Oh, K.W. Anxiolytic-like effects of ginsenosides on the elevated plus-maze model in mice. Biol. Pharm. Bull. 2005, 28, 1621-1625. [CrossRef] [PubMed]

70. Huang, X.P.; Ding, H.; Lu, J.D.; Tang, Y.H.; Deng, B.X.; Deng, C.Q. Effects of the Combination of the Main Active Components of Astragalus and Panax notoginseng on Inflammation and Apoptosis of Nerve Cell after Cerebral Ischemia-Reperfusion. Am. J. Chin. Med. 2015, 43, 1419-1438. [CrossRef] [PubMed]

71. Huang, X.P.; Ding, H.; Wang, B.; Qiu, Y.Y.; Tang, Y.H.; Zeng, R.; Deng, C.Q. Effects of the main active components combinations of Astragalus and Panax notoginseng on energy metabolism in brain tissues after cerebral ischemia-reperfusion in mice. Pharmacogn. Mag. 2015, 11, 732-739. [PubMed]

72. Qi, H.; Huang, Y.; Yang, Y.; Dou, G.; Wan, F.; Zhang, W.; Yang, H.; Wang, L.; Wu, C.; Li, L. Anti-platelet activity of panaxatriol saponins is mediated by suppression of intracellular calcium mobilization and ERK2/p38 activation. BMC Complement. Altern. Med. 2016, 16, 174. [CrossRef] [PubMed]

73. Li, Q.; Guan, Y.; Ma, H.J.; Guo, Z.; He, R.R.; Zhang, Y. Influences of Panax notoginsenosid on spontaneous contraction of small intestine smooth muscle of rabbits in vitro. Zhongguo Ying Yong Sheng Li Xue Za Zhi 2010, 26, 117-120. [PubMed]

74. You, Z.; Yao, Q.; Shen, J.; Gu, Z.; Xu, H.; Wu, Z.; Chen, C.; Li, L. Antidepressant-like effects of ginsenoside Rg3 in mice via activation of the hippocampal BDNF signaling cascade. J. Nat. Med. 2017, 71, 367-379. [CrossRef] [PubMed]

75. Leff-Gelman, P.; Mancilla-Herrera, I.; Flores-Ramos, M.; Cruz-Fuentes, C.; Reyes-Grajeda, J.P.; Garcia-Cuetara Mdel, P.; Bugnot-Perez, M.D.; Pulido-Ascencio, D.E. The Immune System and the Role of Inflammation in Perinatal Depression. Neurosci. Bull. 2016, 32, 398-420. [CrossRef] [PubMed]

76. Wang, J.; Li, D.; Hou, J.; Lei, H. Protective effects of geniposide and ginsenoside Rg1 combination treatment on rats following cerebral ischemia are mediated via microglial microRNA1555p inhibition. Mol. Med. Rep. 2018, 17, 3186-3193. [PubMed]

77. Xu, C.; Teng, J.; Chen, W.; Ge, Q.; Yang, Z.; Yu, C.; Yang, Z.; Jia, W. 20(S)-protopanaxadiol, an active ginseng metabolite, exhibits strong antidepressant-like effects in animal tests. Prog. Neuropsychopharmacol. Biol. Psychiatry 2010, 34, 1402-1411. [CrossRef] [PubMed]

78. Yin, S.; Cheng, Y.; Li, T.; Dong, M.; Zhao, H.; Liu, G. Effects of notoginsenoside R1 on CYP1A2, CYP2C11, CYP2D1, and CYP3A1/2 activities in rats by cocktail probe drugs. Pharm. Biol. 2016, 54, 231-236. [CrossRef] [PubMed]

79. Chen, W.; Dang, Y.; Zhu, C. Simultaneous determination of three major bioactive saponins of Panax notoginseng using liquid chromatography-tandem mass spectrometry and a pharmacokinetic study. Chin. Med. 2010, 5, 12. [CrossRef] [PubMed]

80. Ducottet, C.; Aubert, A.; Belzung, C. Susceptibility to subchronic unpredictable stress is related to individual reactivity to threat stimuli in mice. Behav. Brain Res. 2004, 155, 291-299. [CrossRef] [PubMed]

81. Zhang, C.; Li, C.; Chen, S.; Li, Z.; Ma, L.; Jia, X.; Wang, K.; Bao, J.; Liang, Y.; Chen, M.; et al. Hormetic effect of panaxatriol saponins confers neuroprotection in PC12 cells and zebrafish through PI3K/AKT/mTOR and AMPK/SIRT1/FOXO3 pathways. Sci. Rep. 2017, 7, 41082. [CrossRef] [PubMed]

82. Shi, X.; Yu, W.; Yang, T.; Liu, W.; Zhao, Y.; Sun, Y.; Chai, L.; Gao, Y.; Dong, B.; Zhu, L. Panax notoginseng saponins provide neuroprotection by regulating $\mathrm{NgR} 1 /$ RhoA/ROCK2 pathway expression, in vitro and in vivo. J. Ethnopharmacol. 2016, 190, 301-312. [CrossRef] [PubMed]

83. Yamada, N.; Araki, H.; Yoshimura, H. Identification of antidepressant-like ingredients in ginseng root (Panax ginseng C.A. Meyer) using a menopausal depressive-like state in female mice: participation of 5-HT2A receptors. Psychopharmacology 2011, 216, 589-599. [CrossRef] [PubMed] 
84. Kim, T.W.; Choi, H.J.; Kim, N.J.; Kim, D.H. Anxiolytic-like effects of ginsenosides Rg3 and Rh2 from red ginseng in the elevated plus-maze model. Planta Med. 2009, 75, 836-839. [CrossRef] [PubMed]

85. Xu, D.; Wang, C.; Zhao, W.; Gao, S.; Cui, Z. Antidepressant-like effects of ginsenoside Rg5 in mice: Involving of hippocampus BDNF signaling pathway. Neurosci. Lett. 2017, 645, 97-105. [CrossRef] [PubMed]

86. Jiang, S.; Miao, B.; Song, X.; Jiang, Z. Inactivation of GABA(A) receptor reduces ginsenoside Rb3 neuroprotection in mouse hippocampal slices after oxygen-glucose deprivation. J. Ethnopharmacol. 2011, 133, 914-916. [CrossRef] [PubMed]

87. Cheong, J.H.; Song, M.-R.; Lee, Y.S.; Her, Y.; Yim, D.S.; Ko, H.S.; Ryu, Y.S.; Choi, E.J.; Yoon, S.Y.; Choi, J.H. Anxiolytic and Antidepressant Activities of Ginsenoside Rb1. Biomol. Ther. 2007, 15, 27-33.

88. Churchill, J.D.; Gerson, J.L.; Hinton, K.A.; Mifek, J.L.; Walter, M.J.; Winslow, C.L.; Deyo, R.A. The nootropic properties of ginseng saponin Rb1 are linked to effects on anxiety. Integr. Physiol. Behav. Sci. 2002, 37, 178-187. [CrossRef] [PubMed]

89. Wang, Z.J.; Song, L.; Guo, L.C.; Yin, M.; Sun, Y.N. Induction of differentiation by panaxydol in human hepatocarcinoma SMMC-7721 cells via cAMP and MAP kinase dependent mechanism. Yakugaku Zasshi 2011, 131, 993-1000. [CrossRef] [PubMed]

90. Wu, C.F.; Liu, Y.L.; Song, M.; Liu, W.; Wang, J.H.; Li, X.; Yang, J.Y. Protective effects of pseudoginsenoside-F11 on methamphetamine-induced neurotoxicity in mice. Pharmacol. Biochem. Behav. 2003, 76, 103-109. [CrossRef]

91. Lee, B.; Sur, B.; Cho, S.G.; Yeom, M.; Shim, I.; Lee, H.; Hahm, D.H. Ginsenoside Rb1 rescues anxiety-like responses in a rat model of post-traumatic stress disorder. J. Nat. Med. 2016, 70, 133-144. [CrossRef] [PubMed]

92. Lee, B.-H.; Kim, H.-J.; Chung, L.; Nah, S.-Y. Ginsenoside Rg(3) regulates GABA(A) receptor channel activity: Involvement of interaction with the gamma(2) subunit. Eur. J. Pharmacol. 2013, 705, 119-125. [CrossRef] [PubMed]

93. Yue, S.-J.; Xin, L.-T.; Fan, Y.-C.; Li, S.-J.; Tang, Y.-P.; Duan, J.-A.; Guan, H.-S.; Wang, C.-Y. Herb pair Danggui-Honghua: Mechanisms underlying blood stasis syndrome by system pharmacology approach. Sci. Rep. 2017, 7, 40318. [CrossRef] [PubMed]

94. Li, J.; Zhao, P.; Li, Y.; Tian, Y.; Wang, Y. Systems pharmacology-based dissection of mechanisms of Chinese medicinal formula Bufei Yishen as an effective treatment for chronic obstructive pulmonary disease. Sci. Rep. 2015, 5, 1-15. [CrossRef] [PubMed]

95. Lee, S.; Rhee, D.K. Effects of ginseng on stress-related depression, anxiety, and the hypothalamic-pituitary-adrenal axis. J. Ginseng Res. 2017, 41, 589-594. [CrossRef] [PubMed] 